2. To: (Receiving Organization)

Distribution

5. Proj./Prog./Dept./Div.:

Saltwell Pumping

8. Originator Remarks:

This EDT is for release/approval of the Functional Design Criteria for Pumping and Instrumentation Control (PIC) Skids.

Keywords: Eunctional Design Criteria, Saltwell Pumping, PIC

11. Receiver Remarks

11A. Design Baseline Document? $\mathrm{O}$ Yes $\bigcirc$ No

\begin{tabular}{|l|l} 
3. From: (Originating Organization) & $\begin{array}{l}\text { 4. Related EDT No.: } \\
\text { Interim Stabilization }\end{array}$ \\
\cline { 2 - 2 } $\begin{array}{l}\text { 6. Design Authority/Design Agent/Cog. Engr.: } \\
\text { J. S. Boettger }\end{array}$ & $\begin{array}{l}\text {. Purchase Order No.: } \\
\mathrm{N} / \mathrm{A}\end{array}$ \\
\cline { 2 - 2 } & 9. Equip./Component No.:
\end{tabular}

$\mathrm{N} / \mathrm{A}$

10. System/BIdg./Facility:

$241-\mathrm{U} / 241 \mathrm{G}$

12. Major Assm. Dwg. No.:

N/A

13. Permit/Permit Application No.:

$\mathrm{N} / \mathrm{A}$

14. Required Response Date:

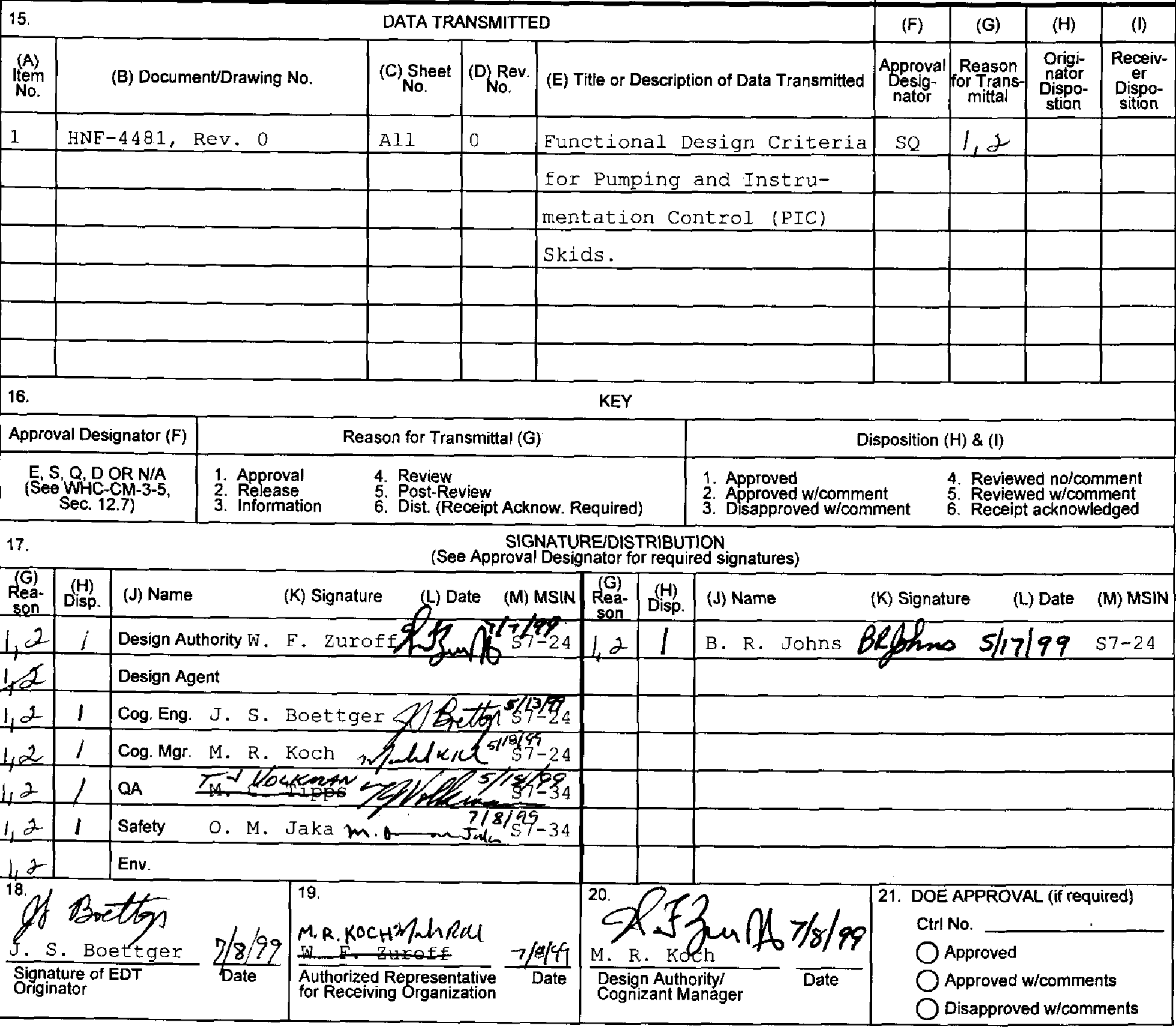

BD-7400-172-2 (10/97)

BD-7400-172- 


\title{
FUNCTIONAL DESIGN CRITERIA FOR PUMPING AND INSTRUMENTATION CONTROL (PIC) SKIDS
}

\author{
J. S. BOETTGER \\ LOCKHEED MARTIN HANFORD COMPANY \\ Richland, WA 99352 \\ U.S. Department of Energy Contract DE-AC06-96RL13200 \\ EDT/ECN: EDT 626388 \\ UC: \\ Org Code: 74 D00 \\ Charge Code: 109433 \\ B\&R Code: EW3120071 \\ Total Pages:
}

Key Words: FUNCTIONAL DESIGN CRITERIA, INTERIM STABILIZATION, PUMPING, PIC SKID

Abstract: THIS DOCUMENT OUTLINES THE FUNCTIONAL DESIGN CRITERIA FOR PUMPING AND INSTRUMENTATION CONTROL (PIC) SKIDS TO SUPPORT THE INTERIM STABILIZATION EFFORT FOR SALTWELL PUMPING.

TRADEMARK DISCLAIMER. Reference herein to any specific commercial product, process, or service by trade name, trademark, manufacturer, or otherwise, does not necessarily constitute or imply its endorsement, recommendation, or favoring by the United States Government or any agency thereof or its contractors or subcontractors.

Printed in the United States of America. To obtain copies of this document, contact: Document Control Services, P.O. Box 950, Mailstop H6-08, Richland WA 99352, Phone (509) 372-2420; Fax (509) 376-4989.
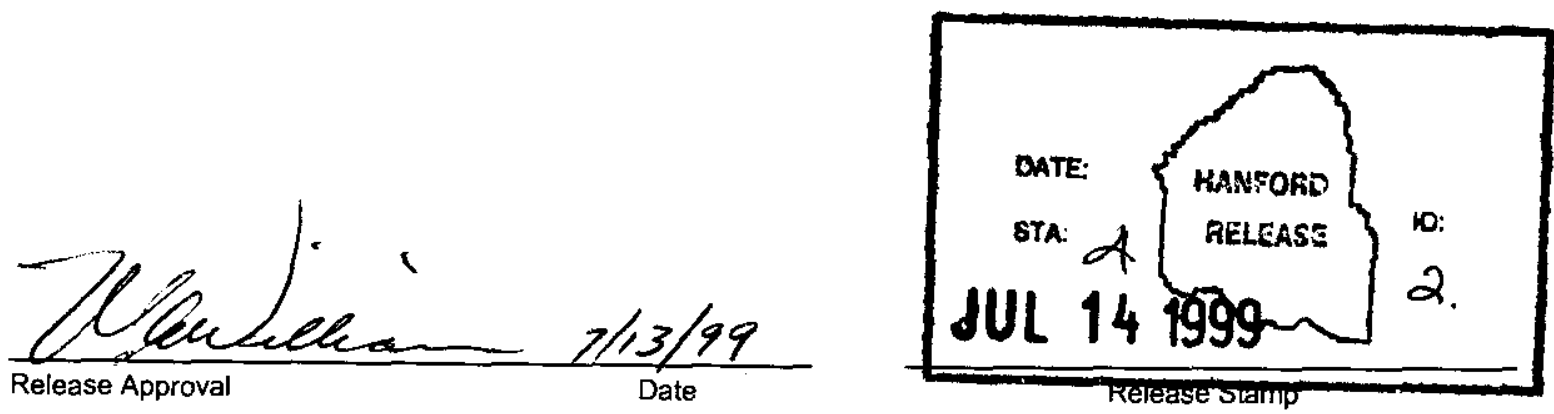

Approved For Public Release 


\section{FUNCTIONAL DESIGN CRITERIA FOR PUMPING AND INSTRUMENTATION CONTROL (PIC) SKID}

\subsection{INTRODUCTION}

Radioactive liquid and semisolid waste from operation of Hanford's nuclear fuel processing plants is stored in 177 underground storage tanks located in the 200 Areas of the Hanford site. 28 of these tanks are of double-shell construction. The remaining 149 tanks are of single-shell construction. Only the newer, double-shell tanks (DST) can meet current requirements for containment of dangerous waste. Therefore, the singleshell tanks (SST) are being "interim stabilized," which is the process of removing liquid from the waste through the use of a jet pump installed in a saltwell which penetrates the waste.

Lockheed Martin Hanford Company has decided to purchase additional Pumping and Instrumentation Control (PIC) skids to monitor and control the operation of saltwell jet pumps in SSTs. Similar PIC skids are already in use at several locations. The PIC skids will shut off all power to equipment/instruments if preset limits are exceeded for such conditions as flammable gas, leak detection, pressure and flow, as well as provide air and water necessary for saltwell pumping activities.

\subsection{FUNCTIONAL DESIGN CRITERIA}

\section{$2.1 \quad$ System}

The basic functions of the PIC skid are to:

- Monitor the performance of the saltwell pumping operation.

- $\quad$ Provide air and water for use during saltwell pumping activities.

- $\quad$ Shut off the power to the saltwell pump and other energized equipment/instruments in the pump pit when conditions arise that could make its continued operation dangerous.

The PIC skid could be installed at any tank farm with single-shell tanks and be remotely operated while the saltwell pumps are running. The following criteria are applicable:

The PIC skid shall be able to interface with the existing configuration at any single-shell tank that will be pumped. 
The PIC skid shall incorporate provisions to facilitate maintenance, calibration, inspection, and testing. Provisions shall be incorporated to simulate as nearly as practical the conditions under which the PIC skid is designed to operate, for test purposes.

To the extent practicable, the PIC skid shall be designed such that replacement parts are readily available and easily installed.

The PIC skid shall be able to measure and display both suction and discharge pressure from the saltwell pump. Suction pressure is typically measured in the range of $0-100 \mathrm{psig}$. Discharge pressure is typically measured in the range of 0-300 psig. Also, the PIC skid shall be able to measure and display output flow through the transfer line and pump recirculation flow.

The PIC skid shall be able to monitor and control the temperature of pump/jumper piping.

The PIC skid shall be designed to measure waste liquid level and specific gravity of tank waste.

\subsection{System Enclosures}

Location: The PIC skid shall be designed to allow for installation in an unsheltered area of any single-shell tank farm. It is anticipated that supplementary heating/cooling may be required.

Environment: The PIC skid shall be able to function in the local environment at the Hanford tank farms for a period of time which may exceed two years. Ambient conditions can be considered to range from -29 to $49 \mathrm{C}$ ( -20 to $120 \mathrm{~F})$ with winds up to $145 \mathrm{kph}(90 \mathrm{mph})$. The relative humidity ranges from 5 to $100 \%$. Rain, snow, sleet, hail, volcanic ash, blowing dust and sand, and lightning strikes are all possible occurrences. A National Electrical Manufacturers Association (NEMA) 3R or 4X metal enclosure shall be employed to deal with these conditions.

Thermal Protection: The enclosures shall be designed to prevent freezing of piping and instrumentation. Also, the enclosure housing the Programmable Logic Controller (PLC) shall be maintained at a temperature below 49C (120F).

\subsection{Instrument Air System}

The instrument air system shall be designed to provide instrument quality air at an average nominal system demand of $34 \mathrm{SCFH}$ with occasional peak demand of $57 \mathrm{SCFH}$, at a pressure of $70 \pm 5$ psig or greater. In addition, the system shall be designed to provide an additional 10.6 SCFH for each flammable gas monitor used in the system. 
The compressor shall be sized for nominal demand plus reasonable losses due to leakage, with an average duty cycle of $50 \%$ or less. The system shall be designed to operate outdoors under Hanford site conditions with minimal operator interface.

\subsection{Water System}

The water system shall be able to supply water from a storage tank at a regulated pressure of 25-50 psig, using static air pressure from instrument air system or other compressed air source. The storage tank shall hold sufficient water supply for 30 days ( $\sim 80$ gallons) or as long as practical, and shall be capable of being refilled from a water truck. Instrumentation shall include a tank pressure gauge and an indicator for tank water level.

\subsection{Electrical Power}

The PIC skid shall receive $480 \mathrm{v}, 3$ phase power, and shall be capable of providing 120, 240 and $480 \mathrm{VAC}$ for necessary equipment.

\subsection{System Software}

The PIC requires the use of a programmable logic controller (PLC) to both monitor and control certain aspects of the pumping operation. The PLC must be sized adequately to handle the following inputs/outputs:

The PLC shall be designed to receive an input signal from an alarming leak detector and be able to shut down the saltwell pump.

The PLC shall be designed to receive an input signal (directly or indirectly) from a pressure switch or pressure transmitter and be able to shut down the saltwell pump. Transfer system pressure switches are dual acting and typically activate at 10-15 psig on decreasing pressure and 140-150 psig on increasing pressure. Service water pressure switches or pressure transmitters with alarms are required to activate at less than or equal to 20 psig on increasing pressure.

The PLC shall be able to receive an alarm signal from a Flammable Gas Monitor (FGM) and shut down the saltwell pump upon flammable gas concentrations greater than $25 \%$ of the Lower Flammability Limit (LFL) of hydrogen.

The PLC shall be capable of monitoring pump/jumper pressures and temperatures, valve positions, instrument cabinet temperatures, waste stream parameters (specific gravity, weight factor, flow rate) and water tank level. 
The PLC shall include a communication port, (typically DH485), and be programmable for remote communication with other PLCs.

\subsection{SAFETY}

HNF-SD-WM-BIO-001, Basis for Interim Operation (BIO), identifies potential accident scenarios and the equipment necessary to prevent or mitigate these accidents. The equipment relevant to the saltwell pumping operation include leak detection, service water pressure detection, and saltwell flow totalizers. Leak detectors and service water pressure detection systems, are Safety Class (SC) and saltwell flow totalizers are Safety Significant (SS) as defined in the BIO.

Items identified in the BIO as Safety Class or Safety Significant shall be procured per the guidelines identified in HNF-PRO-1819 and HNF-IP-0842, Volume IV, Section 4.21.

\subsection{Leak Detection}

The PIC skid must be able to receive a signal from an alarming/failed leak detector and shut down pumping operations. Typically, two leak detector circuits will be required per PIC skid. The Safety Class components of this circuit are the trip amplifier and the control relay. Both of these components are intrinsically safe.

The function of the trip amplifier is to monitor the leak detector circuit to ensure its operability, while the function of the control relay is to ensure any leak detected results in a shutdown of pumping operations.

\subsection{Service Water Pressure Detection}

The function of the service water pressure detection system, is to prevent backflow of waste into the service water. Two types of pressure detection are typically used: Pressure switches and pressure transmitters.

Pressure switches, when tripped, send an alarm signal directly to the PLC, initiating shutdown of pumping operations.

Pressure transmitters continuously monitor pressure and send a signal to an indicator in the PIC Skid. When the pressure reaches a pre-established setpoint (typically $15 \mathrm{psig}$ ), the indicator sends an alarm signal to the PLC to initiate pump shutdown. 


\subsection{Flow Totalizer}

The function of the flow totalizer is to measure the flow of waste through the transfer piping and accumulate total waste transferred. The typical range of the flow totalizer is $0-4 \mathrm{gal} / \mathrm{min}$. Flow is measured at the pump/jumper assembly piping and a signal is sent to the totalizer located in the PIC Skid.

\subsection{Intrinsically Safe (IS) Wiring}

The PIC skid shall be capable of providing an isolation barrier to isolate in-pit equipment (such as pressure, switches, flowmeters, leak detectors, and alarm contacts) from external spark sources. Wiring associated with this equipment must pass through a qualified IS panel.

\subsection{INDUSTRIAL CODES AND STANDARDS}

The PIC skid design and fabrication shall comply with the codes and standards listed below.

NEMA, 1985, Enclosures for Electrical Equipment (1000 Volts Maximum), NEMA 2501985, National Electrical Manufacturers Association, Washington, District of Columbia.

NFPA, 1998, National Electric Code, NFPA-70-1998, National Fire Protection Association, Quincy, Massachusetts.

\subsection{TANK FARMS OPERATING SPECIFICATION DOCUMENTS}

Operating Specifications for Single-Shell Waste Storage Tanks, OSD-T-151-00013. (Latest Revision).

Operating Specifications for Watch List Tanks, OSD-T-151-00030. (Latest Revision).

\subsection{U.S. DEPARTMENT OF ENERGY GENERAL DESIGN CRITERIA}

DOE, 1989, General Design Criteria, DOE-6430.1A/P, U.S. Department of Energy, Washington, District of Columbia. 
HNF-4481

Rev. 0

7.0 REFERENCES

Page 7 of 7

Fluor Daniel Hanford, Tank Waste Remediation System Basis for Interim Operation, HNF-SD-WM-BIO-001.

Fluor Daniel Hanford, Tank Waste Remediation System Technical Safety Requirements, HNF-SD-WM-TSR-006.

Fluor Daniel Hanford, Tank Farms Operations Administrative Controls, HNF-IP-1266, Rev. 1, August 8, 1997. 